\title{
ATHENS VERSUS JERUSALEM? THE ATTITUDE TOWARDS SCIENTIFIC KNOWLEDGE IN BYZANTIUM ${ }^{1}$
}

\author{
Tatyana A. Senina (nun Kassia) \\ Saint Petersburg State University of Aerospace Instrumentation; \\ Sociological Institute, RAS, Saint Petersburg, Russian Federation
}

\begin{abstract}
There was a considerable shift towards 'profane' Hellenistic knowledge in Byzantium during time as Byzantines refrained themselves from complete rejection of the 'pagan wisdom', which characterized the early Christianity, and allowed it as an educative and rhetorical tool against heretics. By the $9^{\text {th }}$ century, Christians didnt need to stand the competition with pagan religion any longer and the interest in Hellenistic culture soared. In the $11^{\text {th }}$ century, intellectuals not only studied Greek and Roman authors but also sometimes used their views as the basis of afterlife explanation of the worldview competing with Orthodox ones. The $14^{\text {th }}$ century witnessed the progress of this approach in praising the 'theoria of beings' instead of the mystic 'theoria of God', which was put as an ideal of an educated man by Byzantine intellectuals. This was a base for fruitful development of science. The worldview of Byzantine humanists based on ancient culture was in strong opposition to the Church, bringing itself from rigid Orthodoxy to experiments with pagan philosophy and scientific research. The Hesychast discussion that arose soon followed by victory of Palamism created different attitudes as Gregory Palama stated that science is useless and, even more, harmful for piety. George Gemistos Plethon confronted this conservatism by his views, which, however radical, were extension of Byzantine philosophy of previous centuries. The highest arete for Plethon was not a complete refusal of everything mundane for God's sake but was a sort of scientific and philosophical realization of reality: a man is 'a spectator at a feast' of life having the vocation to watch the being. All in all, the Plethon's credo, being free of Christian paradigm, is a real hymn to reason and science.

Key words: Byzantine history, history of science, Christianity, secularism, humanism.

Citation. Senina T.A. (nun Kassia). Athens Versus Jerusalem? The Attitude Towards Scientific Knowledge in Byzantium. Vestnik Volgogradskogo gosudarstvennogo universiteta. Seriya 4, Istoriya. Regionovedenie. Mezhdunarodnye otnosheniya [Science Journal of Volgograd State University. History. Area Studies. International Relations], 2017, vol. 22, no. 5, pp. 192-204 (in Russian). DOI: https://doi.org/10.15688/jvolsu4.2017.5.18
\end{abstract}

УДК 94“04/14”:061.22

Дата поступления статьи: 22.03.2017

ББК 63.3(0)4-9

Дата принятия статьи: 25.09.2017

\section{АФИНЫ VERSUS ИЕРУСАЛИМ? ОТНОШЕНИЕ К НАУЧНОМУ ЗНАНИЮ В ВИЗАНТИИ ${ }^{1}$}

\author{
Татьяна Анатольевна Сенина (монахиня Кассия) \\ Санкт-Петербургский государственный университет аэрокосмического приборостроения; \\ Социологический институт РАН, г. Санкт-Петербург, Российская Федерация
}

\footnotetext{
Аннотация. Отношение к светской, «эллинской» учености в Византии менялось со временем. Византийцы - отказались от неприятия первыми христианами любой «языческой» мудрости, допустив ее изучение для общего образования, а также в качестве инструмента в спорах с еретиками. К IX в. христиане перестали опасаться конкуренции с религией язычников, и интерес к эллинской культуре стал быстро повышаться. В ХІ в. интеллектуалы не $\mapsto$ только изучали античных авторов, но порой пытались с опорой на их взгляды дать окружающей действительности ॠ объяснения, альтернативные православным. К XIV в. византийские ученые продвинулись по этому пути еще дальше, вместо мистического созерцания Бога прославляя «созерцание сущих», научно-теоретическое познание действительности как жизненный идеал образованного человека - установка, плодотворная для дальнейшего развития наук. Мировоззрение византийских гуманистов основывалось не только на любви к античной культуре,
} 
но противостояло церковному истеблишменту, выходя из жестких рамок православия на поле экспериментов с языческой философией, к философскому, а в перспективе и к научному поиску. Но вскоре в Византии возник спор об исихазме, и победа паламитов вызвала рост иных настроений: Григорий Палама в пылу полемики угверждал, что светские науки не нужны и даже вредны для благочестия. Ответ на такой консерватизм дал в XV в. последний философ Византии - Георгий Гемист Плифон, чьи взгляды, несмотря на радикальность, философски были развитием предыдущих тенденций византийской мысли. Высшая добродетель для Плифона состояла не в отречении от всего вещественного ради созерцания Бога, а в научном и философском осмыслении действительности: человек это «зритель на празднике» жизни, призванный наблюдать за сущими и исследовать их. В целом жизненная философия Плифона, свободная от рамок христианской парадигмы, является настоящим гимном разуму и науке.

Ключевые слова: история Византии, история науки, христианство, секуляризм, гуманизм.

Цитирование. Сенина Т. А. (монахиня Кассия). Афины versus Иерусалим? Отношение к научному знанию в Византии // Вестник Волгоградского государственного университета. Серия 4, История. Регионоведение. Международные отношения. - 2017. - Т. 22, № 5. - C. 192-204. - DOI: https://doi.org/10.15688/jvolsu4.2017.5.18

Светское знание и христианский гнозис или, говоря по современному, наука и религия на протяжении христианской истории постоянно пребывали в большем или меньшем антагонизме. Основу для него заложил еще апостол Павел, когда сказал, что Бог «мудрость мира сего обратил в безумие» (1 Кор. 1:19). У христиан первых веков, по-видимому, было популярно буквальное понимание этих слов, поскольку в «климентовых» Апостольских постановлениях - тексте IV в., но отражающем более раннюю традицию - мы находим такое поучение:

«От всех книг языческих удерживайся. Ибо на что тебе чужие речи, или законы, или лжепророки, когда они даже отвращают слабых от веры? Чего не достает тебе в Законе Божием, чтобы устремляться тебе к тем басням, языческим? Хочешь ли ты проходить сочинения исторические? Имеешь книги Царств. ...Желаешь ли ты сочинений лирических? Имеешь псалмы. Древностей ли желаешь? Имеешь Бытие. Сочинений ли о законах и заповедях желаешь? Имеешь славный Закон Господа Бога. Итак, от всего чуждого и дьявольского воздерживайся усиленно» $[1$, I.6].

Однако в Византии, благодаря в первую очередь отцам-Каппадокийцам, отношение к светской, «эллинской» образованности несколько меняется: «внешняя» ученость не считается безоговорочно «чуждой и дьявольской» и поощряется хотя бы в виду того, что христиане должны быть достаточно подкованными, чтобы уметь возражать еретикам и отстаивать веру. Св. Григорий Богослов сказал об этом так:
«Полагаю, что всякий, имеющий ум, признает первым для нас благом ученость, и не только эту благороднейшую и нашу ученость, которая ...емлется за единое спасение и за красоту умосозерцаемую, но и ученость внешнюю, которой многие из христиан, по худому разумению, гнушаются как злохудожной, опасной и удаляющей от Бога. Небо, землю, воздух и все, что на них, не должно презирать за то, что некоторые худо уразумели и вместо Бога воздали им божеское поклонение. ...Так и в науках мы заимствовали исследования и умозрение, но отринули все то, что ведет к демонам, к заблуждению и в глубину погибели. Мы извлекли из них полезное даже для самого благочестия, через худшее научившись лучшему и немощь их обратив в твердость нашего учения. Поэтому не должно унижать ученость, как рассуждают о сем некоторые, а, напротив того, надобно признать глупыми и невеждами тех, которые, держась такого мнения, желали бы всех видеть подобными себе, чтобы в общем недостатке скрыть свой собственный недостаток и избежать обличения в невежестве» $[4$, с. 515-516].

Науки и научная деятельность в Византии, конечно, отличались от современных, однако интересно проследить за тем, как менялось отношение к ним, поскольку очевидно, что одни взгляды на научные занятия способствуют дальнейшему развитию наук, а другие тормозят его.

Школьное образование в Византии всегда оставалось светским и не переходило в ве́дение Церкви [6, с. 65-69], а обучение велось в основном по сочинениям античных авторов, хотя позднее к ним прибавились и христианские, поэтому наставление св. Василия Великого К юношам о том, как получать пользу из языческих сочинений оставалось актуальным: полезное для воспитание добро- 


\section{ВИЗАНТИЙСКИЙ МИР}

детелей и для общего образования оттуда можно брать, а все, что противно благочестию и христианскому учению, надо пропускать мимо ушей [см.: 3]. Знания же о природе считались в целом нейтральными, и Василий Великий в Беседах на Шестоднев использовал все естественнонаучные знания своего времени, сводившиеся, прежде всего, к корпусу сочинений Аристотеля.

В V в. Сократ Схоластик в Церковной истории, рассказав о провалившейся при Юлиане Отступнике попытке верующих перевести образование на тексты христианского содержания, заметил, что «эллинская образованность ни Христом, ни Его учениками не была ни принята как богодухновенная, ни отвергнута как вредная», и это промыслительно, поскольку «многие из философствовавших у эллинов были недалеки от познания Бога» и боролись против «учивших об отсутствии провидения», а Священное Писание, сколь бы ни было велико и божественно «не научает искусству красноречия, посредством которого можно было бы опровергать врагов истины, враги же побеждаются преимущественно тогда, когда против них употребляют их же оружие» [28, III.16].

Такое отношение к мирской учености и античному наследию в Византии сохранялось на протяжении столетий: светская образованность считалась допустимой и, в виду определенных целей, желательной, если только не уводила от христианской веры и благочестия. Но считали ли византийцы, что научными занятиями можно каким-то образом служить Богу и угождать Ему? Как кажется, некое подтверждение этому можно найти у св. Максима Исповедника. Истолковывая дары, принесенные ветхозаветными иудеями для строительства скинии - храма Божия, - он говорит, что приносившие пурпур это те, «Кто в точности и без изъяна воспринял знание о сущем, ибо, по одному из мнений, пурпур понимается как знание, поскольку он слагается из множества разнообразных видов, подобно тому как и знание слагается из множества

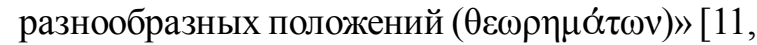
c. 161, Трудность 137].

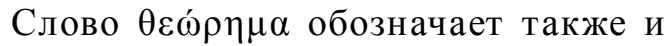
«представление» или «умозрение», но в целом рассуждение Максима можно понимать в том смысле, что верные понятия о сущем, добытые с помощью наук, также могут являться приношением Богу. Это логично: коль скоро наука изучает тот самый мир, который создал Бог, а разум, способный заниматься научным поиском, дан человеку Богом, то любое истинное понятие об этом мире некоторым образом приближает к его Творцу. Разумеется, Максим, как и другие отцы Церкви, высшим знанием считал познание Бога через непосредственное созерцание, а не через изучение Его творений, да и тогдашние понятие о познании сущих были не тождественны современным научным знаниям о мире. Однако в целом толкование Максима, как кажется, позволяет включить занятие науками в число богоугодных дел.

В IX в. Византия пережила всплеск интереса к античному наследию: тогда были переписаны сохранившиеся к тому времени произведения древних авторов, и именно благодаря любознательным интеллектуалам той эпохи они дошли до нас. П. Лемерль связывает это явление с тем, что к тому времени христиане уже не опасались конкуренции с религией язычников и перестали бояться их книг [6, с. 155-156, 444]. Однако к заметному развитию наук это не привело. Лучшие силы византийских интеллектуалов по-прежнему уходили на полемику с еретиками, изобретение богословских тонкостей и экзегетические сочинения или на составление флорилегиев и антологий. Знаменательно, что в IX-X вв. в соседнем с Империей арабском Халифате, где происходил заметный подъем наук, византийцев не считали нацией ученых. Арабский автор $\mathrm{X}$ в. передает рассказ об известном писателе и переводчике персе Ибн ал-Мукаффу, который на вопрос, какой народ превосходит всех своей мудростью, ответил, что персы не таковы, поскольку занимаются лишь подражанием и делают по образцам, «нет у них изобретательности и добывания»; не таковы и византийцы: «у них крепкие тела, они строители и механики, кроме этого они ничего не умеют и ничего другого не делают лучше» [2, с. 375]. Ал-Масуди об учености христиан писал так:

«Не переставали существовать высокая мудрость во времена древних греков, возвеличение ученых и почитание мудрецов. Имелись у них суж- 
дения о темпераменте и теле, и разуме, и душе, и изучение четырех наук, а именно: ал-аритметики, а это - наука о счете, ал-джуметрики, а это - наука землемерия и механики, и ал-астронумии, а это наука о звездах, и ал-мусики, а это - наука о составлении мелодий. И не переставали эти науки быть в действии, освещающими страны, сильными в обучении, крепкими в защите, высокой постройки до тех пор, пока не появилась христианская вера в арРуме, и стерлись знания мудрости, исчезли их следы, и пропали их пути, и пропало то, что выяснили древние греки и что выявили их предшественники» $[2$, с. 378$]$.

Суждения арабских авторов пристрастны, но определенная правда в них есть: византийцы в самом деле не были склонны к научному поиску в духе древних греков. Как заметил О.Г. Большаков, развитию наук в Халифате IX-X вв., где уровень культурного развития был гораздо ниже современной ему Византии, «способствовало именно отсутствие в исламе в ту пору разработанной религиозно-философской системы. Религия и наука существовали параллельно, мусульманская идеология не поднялась еще до того уровня, когда она могла оказать идеологическое влияние. Оно стало ощущаться только в XI в., когда развитие науки в мусульманских странах явно замедлилось, и ситуация в них стала подобной той, которая сложилась ранее в Византии» [2, с. 378].

Тем не менее, после «первого византийского гуманизма» IX в. интерес к эллинской культуре, философии и особенно платонизму неуклонно повышался, так что к XI в. в церковных кругах возникло определенное беспокойство. В связи с деятельностью Иоанна Итала была даже принята анафема на тех, кто исследует «эллинские учения не только ради образования», но принимает изложенные там мнения ( $\left.\delta \sigma^{\xi} \alpha l\right)$ как истинные и учит им других $[19$, р. 59.214-218], - недвусмысленное выражение отношения православных фундаменталистов к светской науке. Хотя в последующих анафемах проклятию подвергаются в основном околорелигиозные философские мнения: платоновские идеи, учения о демиурге, переселении душ и т. п., в данной анафеме, тем не менее, не уточняется, каким именно «мнениям» из числа эллинских учений возбраняется следовать, и ее легко распространить вообще на все «внешние» по отношению к христианству идеи. Ради образования читать эллинские сочинения по-прежнему не возбранялось, но можно, конечно, поспорить о ценности образования, при котором заведомо предполагается, что все прочитанное в нехристианских книгах следует считать неистинным и всегда предпочитать мнения христианских писателей (мы увидим, к каким воззрениям на науку это привело позднее у св. Григория Паламы).

Впрочем, знания византийских интеллектуалов были в основном книжными, то есть носили теоретический характер. В этом вообще состояла специфика византийской образованности: понятие «науки» для византийцев имело иной смысл, нежели сейчас. В наше время научные занятия, особенно занятия естественными и точными науками, предполагают изучение природы, научный поиск, выдвижение теорий и гипотез и экспериментальные исследования ради их подтверждения или опровержения. Для византийцев же занятия науками подразумевали прежде всего накопление определенной суммы знаний и умение ими блеснуть. Хотя в систему высшего образования входили математика и астрономия, а такие интеллектуалы как патриарх Фотий или Михаил Пселл имели представления, например, о медицине и могли ставить диагнозы больным, самыми важными науками в любом случае считались философия и словесность, умение выражать мысли, убеждать, опровергать противников.

Что касается естественных наук, то можно лишь посетовать на то, что византийцы веками переписывали сочинения Аристотеля или воспроизводили мнения других античных авторов, практически не предпринимая попыток их уточнить или дополнить. В XIV в. Феодор Метохит писал, что по истории животных, метеорологии и физике, также как по логике и аподиктике, не было других сочинений и их изучали по Аристотелю [30, p. 27-28]. Можно, конечно, объяснить это явление тем, что образованные аристократы или монахи, которые чаще всего являются авторами дошедших до нас сочинений, исследованием природы не занимались. Но в реальности дело тут в том, что по менталитету они были скорее архивариусами, чем естествоиспытателя- 


\section{ВИЗАНТИЙСКИЙ МИР}

ми, и считали, что теоретическое знание в любом случае выше какого бы то ни было его применения на практике. Так, император Феодор II Ласкарис писал, что великие ученые изучают науки лишь в теории, а практикой не занимаются, поскольку их не интересует материальный результат их исследований [24, p. 27-28]. Конечно, существовала обширная практика в таких областях как медицина или строительство и механика, но мы, к сожалению, знаем об этой стороне жизни византийцев гораздо меньше, чем об их литературных и философских занятиях и теоретических рассуждениях об устройстве мира. Зато под предлогом чисто теоретического интереса византийские интеллектуалы могли изучать по книгам среди прочего оккультные науки, формально противоречащие христианству, например, астрологию. Известно, что Михаил Пселл интересовался алхимией, однако подчеркивал при этом, что изучает ее не с практической целью, а лишь с познавательной, - по тем временам это было способом обезопасить себя от обвинений в колдовстве [24, p. 29]. Алхимические сборники того времени включали в себя не только описания получения философского камня и золота, но и чисто практические рецепты - например, по окраске стекла или тканей, производство золотых чернил и пурпура и т. д. - и эти тексты продолжали переписываться в Византии, но об алхимической практике той эпохи мы почти ничего не знаем [25, р. 209, 224-228].

Люди, не удовлетворявшиеся одними книжными знаниями и пытавшиеся как-то экспериментировать, нередко подвергались яростным нападкам. Иконоборческого патриарха IX в. Иоанна Грамматика иконопочитатели обвиняли в колдовстве, гаданиях и попытках управлять «стихиями» через константинопольские статуи. Св. Мефодий в каноне на Торжество православия, сравнивает Иоанна с Пифагором и Аполлоном, называет «равным эллинам» и упрекает за «дельфийский образ действия» [13, с. 34-38]. Современные исследователи предполагают, что Иоанн мог ставить какие-то полуоккультные опыты и изучать астрологию и практические возможности предсказания будущего [18, p. 28; 22, p. 123 $125,128-129,132-135]$. В колдовстве и «эллинстве» обвиняли и других ученых людей той эпохи, например, патриарха Фотия и Феодора Сантаварина [22, р. 125-127, 131-132], Льва Хиросфакта [20, р. 68-71].

Но, хотя ученым людям и угрожало обвинение в «нечестии», любознательность побеждала. Михаил Пселл утверждал, что «те, кто не изучил египетскую, халдейскую и эллинскую мудрость, те, кто не познал эллинские науки и не использовал всего, что есть в них полезного, должны стыдиться своего невежества» [7, с. 260]. Ему принадлежит еще более яркое высказывание:

«Нередко наедине с собой мысленно кладу я на чаши весов свое достояние. На одну - прегрешения против Бога, на другую - то, что приобрел из книг своим рвением. Сравнив то и другое, я понимаю, что худого у меня больше, нежели хорошего, но этим малым я горжусь сильнее, чем огорчаюсь многим» [7, с. 309].

Знаменательно, что Пселл противопоставляет грехи не христианским добродетелям, а научным знаниям, и этими знаниями гордится, - позиция, может быть, не слишком подобающая благочестивому христианину, но понятная и созвучная ученому. Несмотря на ориентацию византийских интеллектуалов на исключительно «книжное» знание, тот факт, что ученые люди вроде Пселла, по сути, дорожили мирской ученостью более, чем добродетелями, заслуживает внимания, поскольку в перспективе это открывало возможности для развития науки.

Деятели эпохи «второго византийского гуманизма», интеллектуалы XIV-XV вв. пошли по этому пути еще дальше. В это время необычайное развитие получает культ античности и античной науки. Как заметил И.П. Медведев, в сочинениях ученых той эпохи выражен их интеллектуально-эстетичес-

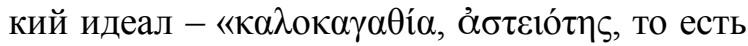
благородство и утонченность, идеал, заимствованный из античности, но выражавший новое эстетическое восприятие жизни, идеал, в котором сплавились воедино нравственные качества человека и его энциклопедизм и в котором ясно различима ренессансная идея гармонии рационального и прекрасного» [9, с. 32]. Хотя эти византийские интеллектуалы были христианами и порой оканчивали жизнь в монашестве, в их сочинениях мы не встретим 
того противопоставления «внешней» и «христианской» учености, того унижение эллинской образованности и светского знания, которые так часто встречаются у церковных авторов. Идеалом человека для византийских гуманистов был не монах-подвижник, а всесторонне образованная высококультурная личность. Никифор Григора, характеризуя Феодора Метохита, в одном из писем восхваляет его за знание всех наук своего времени и говорит: «Если бы тебя прозвали Искусством искусств, Наукой наук, самим Знанием реальности, то попали бы в самую цель» [9, с. 114].

Сам Метохит считал лучшей из всех способностей человека «способность хорошо помнить то, что увидел и почерпнул каждый раз из речей или из всяких дел», поскольку «без памяти совершенно невозможна была бы любая наука и занятие в жизни, а в особенности пользование самой мудростью, поэтому способность помнить - наилучшая из всех», и для успехов в обучении нужно соединить

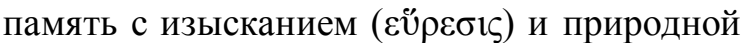
проницательностью [30, p. 18-19]. Он не абсолютизировал монашество в качестве идеала и даже говорил, что полное отрицание жизни в обществе и в семье равнозначно отрицанию Божия творения.

В трактате Этический, или $O$ воспитании Метохит восхваляет красоту жизни в науке и говорит, что научные занятия доставляют человеку высшее наслаждение (市ovท́). Он прославляет «созерцательную жизнь»

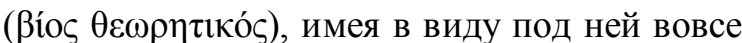
не жизнь монаха-исихаста, а жизнь ученого. Для византийских интеллектуалов подобных Метохиту вожделенная $\theta \varepsilon \omega \rho i ́ \alpha$ была не мистическим созерцанием, а «созерцанием сущих» [30, 15, cp. 16 ff.] - научно-теоретическим, философским познанием действительности и естественной формой жизни, в которой образованный человек может осуществить свой жизненный идеал [9, с. 117-119]. Наука для них в какой-то степени занимает место Божества: например, Метохит писал, что ученому хорошо отказаться от мирских забот и от брака ради науки, а не ради Бога, поскольку семейная жизнь отвлекает от занятий [9, c. 32-33]. Византийские интеллектуалы нередко выражали желание написать такое сочинение, которое обессмертило бы их [9, c. 33], - тоже не христианский мотив, ведь с точки зрения благочестие бессмертие можно стяжать только добродетелью (мотив, часто встречающийся в житиях святых). Зато можно вспомнить слова Платона о творчестве: «каждый, пожалуй, предпочтет иметь таких детей, а не обычных, если подумает о Гомере, Гесиоде и других прекрасных поэтах, чье потомство достойно зависти, ибо оно приносит им бессмертную славу и сохраняет память о них, потому что и само незабываемо и бессмертно» [12, с. 120: Пир, 209d].

Очевидно, что такая жизненная установка византийских интеллектуалов была плодотворной для дальнейшего развития наук. Однако спустя менее двух десятков лет после смерти Феодора Метохита в Византии разразился спор об исихазме и статусе божественных энергий, в котором победили сторонники св. Григория Паламы. Результаты этой победы, к сожалению, для судеб византийской науки были плачевны, так как паламиты сделали ставку на охранительный консерватизм, причем воинственного толка. Поскольку главный противник Паламы Варлаам Калабрийский утверждал, что духовное совершенство невозможно без усовершенствования разума светскими науками, Палама в пылу борьбы заявил, что эти науки не просто не нужны, но даже и вредны для благочестия. Познание «внешних наук» он назвал «плотским и природным даром», сравнив его с «удовольствием в законных браках» [5, I.1.22; cp. II.1.35],это вполне можно истолковать как прозрачный намек на то, что человек не только может прожить без научных знаний, как и без брака, но что ему даже и лучше прожить без них, ибо это добродетельно. Называя «внешнюю», то есть нехристианскую мудрость «суетной и презренной» [5, I.1.23], Палама ополчается на тех, кто занимается ею:

«...есть люди, с невероятным бесстыдством объявляющие, что заниматься всю жизнь эллинской наукой вовсе не помеха для совершенства жизни ...Знание надмевает. Видишь? Венец зла, главнейший диавольский грех - гордость - возникает от знания! ... Знание надмевает, а любовь созидает (1 Кор. 8:1)....Если даже такое знание ${ }^{2}$ надмевает, тем более надмевает то, о котором у нас речь: ведь оно вообще природно и присуще ветхому челове$\kappa y$ (Еф. 4:22; Кол. 3:9). Именно этому знанию спо- 


\section{ВИЗАНТИЙСКИЙ МИР}

собствует внешняя ученость; а духовного знания так никогда и не будет, если благодаря вере знание не сочетается с любовью к Богу, а вернее - если оно не возродится через любовь и идущую за ней благодать и не станет совершенно иным, новым и боговидным ...Это вот знание и называется мудростью свыше и премудростью Божией (Иак. 3:15$17) ;$...подчиненная премудрости Духа, такая мудрость распознает и приемлет духовные дарования. Другая же мудрость - нижняя, душевная, демоническая, как говорит апостол и брат Господень, почему она и не принимает ничего духовного, ...но считает это глупостью, заблуждением и вымыслом, в большей части пытается полностью опровергнуть и в открытой борьбе извратить и оспорить, как может, а кое-что и лукаво принимает, используя примерно так же, как отравитель - сладкие яства» [5, I.1.9].

Таким образом, по Паламе, заниматься всю жизнь «внешними» науками, «состариться в занятиях» ими [5, II.1.27] - то есть то, чему посвящает жизнь любой ученый - дело неразумное, предосудительное и даже демоническое, увлекающее человека в гордыню и не дающее приблизиться к Богу. При такой установке трудно ожидать, что христианин, всерьез воспринявший это наставление, захочет посвящать свое время наукам: зачем ему мудрость, которую Бог «превратил в безумие» (1 Кор. 1:20) и отверг? Григорий настойчиво отсылает к этому месту из послания апостола Павла [5, II.1.23-24].

Согласно Паламе, Варлаам Калабрийский говорил: «Если Господь не велел в Евангелиях заниматься науками, то и не запретил этого», - то есть повторял то воззрение на ученость, которое проповедовал в V в. Сократ Схоластик в Церковной истории. Варлаам, считая, что человек должен пройти в своей духовной жизни три ступени: деятельность по исполнению заповедей, созерцание природы (к чему относится и научное знание), а потом уже созерцание непосредственно Бога, - опирался на отеческую традицию (в том числе на Максима Исповедника, Дионисия Ареопагита, Евагрия Понтийского и Синезия Киренского) [21]. Но Палама предпочитает этого не замечать и возражает: Христос учил голубиной простоте, и Он же дает истинную премудрость [5, II.1.34], а «змеиная мудрость», упомянутая в Евангелии, означает, что «изобретения внешней мудрости полезны нам, чтобы пользоваться ими против них самих», и толь- ко [5, I.1.11]. Правда, Григорий оговаривается, что он «не лишает монахов словесного научного знания», поскольку до пострига всякий желающий может учиться, однако в монашестве человек уже должен оставить «заботу о многообразных науках» и стремиться «К единовидному свертыванию ума» в молитве [5, II.1.35].

Наконец, Палама заявляет, что многие святые вообще не имели эллинского образования и их мнения об устройстве мира противоречили научному знанию, однако это «случайное незнание» не мешало им быть совершенными [5, II.1.36]. Интересно, что Григорий, когда говорит о таком незнании, приводит в пример мнение, что космос простирается «как шатер» и что небо подобно «своду», а это сказано в Книге Исаии (40:22): Бог «установил небо как свод и распростер как шатер». Хотя, согласно науке, Библия здесь ошибается, Григорий утверждает, что вера как «непоколебимая убежденность» в божественных словах и обетованиях «превосходит любое чувство и любое разумение» [5, II.3.40], ее надо предпочитать всему, и с точки зрения веры научная истина не имеет никакого значения: ведь если бы Авраам или Ной рассуждали о божественных словах с опорой на научные познания, то первый не получил бы сына, а второй утонул бы в водах потопа. «Ты, - обращается Палама к Варлааму, - разыскивая истину сущего [имеется в виду научным путем], уводишь от нее сам себя и тебе поверивших, делаешь жертвами потопа, на горьком опыте учащимися тому, о чем на свою беду не узнали от [мирского] знания»; на самом же деле вера «упраздняет философское знание» [5, II.3.43]. Д. Краусмюллер относительно этих рассуждений Паламы замечает, что здесь недалеко до позиции современных христианских фундаменталистов, которые утверждают, будто Бог сотворил мир за шесть дней вместе со всеми останками ископаемых животных и пр., чтобы испытать веруюших, чему они больше готовы верить Библии или науке [21].

Даже если, продолжает Палама, научное знание истинно, оно имело высокий смысл только до пришествия Христа, когда изучение разумного устройства мира «направляло и обращало род человеческий к Богу» [5, 
II.3.44]; однако теперь, когда через Христа явилась истина и «по Господню обетованию мы ожидаем нового неба и новой земли» (а не тех, которые изучает наука), люди должны «постигать и славить надмирного Бога нового творения», а не «познавать его лишь в ветхом и изменчивом» $[5$, II. 3.45 , сp. I.1.22]. Таким образом, Палама по сути отнимает у познания сотворенного Богом мира всякую ценность, утверждая, что после пришествия Христа следует заниматься только славословием Бога и Его непосредственным созерцанием в надежде на будущую «новую землю» [5, II.3.46].

Д. Макаров попытался оправдать св. Григория от обвинений во враждебном отношении к наукам, указав, что он «придает духовно-интеллектуальной, рассудочно рассудительной и мыслительной деятельности огромное значение» $[8$, с. 200]. Это справедливо, однако, таковую деятельность, по мнению Паламы, следует направлять прежде всего на изучение Библии и отцов Церкви, а также на умную молитву и на познание Бога непосредственным путем. Для мирской учености, увлечения ею и тем более посвящению ей жизни тут нет никакого места.

Н. Синиоссоглу отметил, что мировоззрение византийских гуманистов основывалось не только на любви к античной культуре, но было и противостоянием православному церковному истеблишменту; их «эллинство» выражалось не в возрождении античной религии, а в уходе из жестких рамок православия на широкое поле экспериментов с языческой философией, к философскому - а в перспективе и к научному - поиску. Несмотря на то, что все эти люди были верующими и на словах нередко провозглашали свою приверженность христианским идеалам, их деятельность была попыткой сформулировать новую, секуляризованную философию, новый взгляд на земное предназначение человека. Их гуманизм как интерес к человеческой, земной мудрости, а особенно к платонизму входил в противоречие с православной системе ценностей, что и вызвало резкое противодействие паламитов [27, p. 25-26].

Исихастский спор привел к ожесточению сторон, «привнеся дух нетерпимости в интеллектуальную атмосферу Византии того вре- мени»; противники учения Паламы даже подвергались физической расправе или, по крайней мере, угрозам таковой [9, с. 40-41]. Победившие монахи-исихасты стали, по сути, правительственной партией, в результате чего дух интеллектуальной жизни в Империи изменился. Столичные интеллектуалы стали уезжать в провинцию и за границу, и дело было не только в возраставшей турецкой угрозе: для ученых «интеллектуальный климат возрожденческой Европы, особенно Италии, оказался гораздо более пригодным, нежели нетерпимая идеологическая атмосфера в "исихастской” Византии» [9, с. 55; ср. 29, p. 38].

Центр гуманистической философии в $\mathrm{XV}$ в. переместился на окраину Империи - в Мистру на Пелопоннесе. Именно оттуда дал ответ на паламитский консерватизм последний философ Византии - Георгий Гемист Плифон. Появление этой звезды на небосклоне угасающей Империи само по себе весьма знаменательно: казалось бы, прошло менее ста лет после триумфа исихастов, Григорий Палама признан Церковью как «печать деяний и слов святых» (выражение из Синаксаря Триоди постной на его память во 2-е воскресенье Великого поста), то есть как богослов, осуществивший наилучшим образом синтез святоотеческого учения о Боге и человеке, - и вдруг появляется ученый интеллектуал, стяжавший такой авторитет на родине и за границей, что когда в ту эпоху говорили «Философ», то все сразу понимали, о ком речь [9, c. 183]; и этот философ называет монахов врагами государства, ведущими «образ жизни бездельников и трутней» $[26, \sigma .258, K$ uмnератору Мануилу о положении Пелопоннеca], а вместо христианства разрабатывает собственную религию, основанную на платонизме и системе языческих богов, - и при этом до конца жизни остается любимцем и советником византийских императоров и умирает, почитаемый многочисленными учениками. Поневоле задаешься вопросами: так ли уж триумфальна была победа паламизма? Как развивалась бы интеллектуальная история Византии, если б Империя не ушла из жизни одновременно с ее последним философом?..

Современные исследователи уже отметили, что взгляды Плифона стали ответом на нападки паламитов на светскую ученость и 


\section{ВИЗАНТИЙСКИЙ МИР}

языческую философию и, хотя формально отличались радикальностью, философски были развитием предыдущих тенденций византийской мысли $[9$, с. $64 ; 29$, р. 65-66; 27, р. 3031]. Исходя из понятия об общей гармонии существующего космоса, Плифон считает роль человека уникальной - служить посредником между бессмертной и смертной частями мироздания: «Ведь чтобы Вселенная могла быть полной и законченной, нужно, чтобы она состояла из бессмертного и смертного начал, чтобы она не была ни расколотой, ни раздробленной, но действительно соединялась в некую единую систему» (Законы ${ }^{3}$, III.43).

Никакого понятия о богооткровенной истине Писания у Плифона нет и в помине: рассуждая о том, как выбрать наилучший для человека путь среди существующего разнообразия образов жизни и мнений, он утверждает, что это надо сделать путем «исследования», «рассмотрев, что́ представляет собой человек, каковы его природа и возможности», а для этого «рассмотреть природу вещей», поскольку только тогда «можно будет рассмотреть и человека среди этого всего» (3a$\kappa o н b l, ~ I .1)$. Для такого исследования он привлекает мнения «законодателей и философов», причем среди них нет ни одного библейского или христианского автора (Законьl, I.2-3). Рассуждая о человеке, Плифон полностью обходит стороной концепцию падения человека, греха и благодати. Человек становится благим, «следуя Богу, насколько это возможно», и происходит это благодаря свойственной ему рассудительности (или здравому

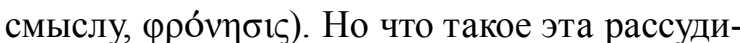
тельность? Согласно Плифону, она делится на три вида: в отношении Бога - богопочитание

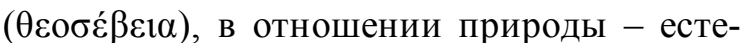
ствознание (фvбıки́), в отношении человеческих дел - благоразумие ( $\varepsilon \dot{\beta} \beta о v \lambda i ́ \alpha)$. Таким образом, следовать Богу человек может через религиозность, научную деятельность и правильное отношение к человеческим делам (O добродетелях ${ }^{4}$, I.3).

«Поскольку человек как таковой, - пишет Плифон, - по своему происхождению - не что иное как некое разумное животное, ясно, что он приведен в этот мир как некий зритель на праздник с целью исследовать по возможности и наблюдать, что́ есть каждое из существ, как они ведут себя между собой и благодаря чему происходит все то, что происходит, - а это, пожалуй, и будет рассудительность, последняя и наиболее совер-шенная часть добродетели, состояние души, созерцающей существующие вещи с целью понять, какой именно каждая из них является» (О добродетелях, I.2).

Итак, высшая добродетель для Плифона состоит вовсе не в мистическом созерцании Бога и отречении от всего вещественного, а в научном и философском осмыслении действительности. Рассуждая о том, как человек через добродетели и разумное воздержание от роскоши учится правильному обращению с людьми и веде́нию дел, Плифон говорит, что такому обученному человеку «гораздо легче приобрести благоразумие», и продолжает:

«Ведь известно, как сильно человек ученый отличается от неученого, а рассматривающий что бы то ни было с разумением (бن̀v $\lambda{ }^{\prime} \gamma(\mathfrak{)})$ - от того, кто судит без разумения; а потому осуществлению любой из жизненных задач много способствует точное знание человеческих дел, а вместе с тем наблюдение ( $\theta \varepsilon \omega \rho i ́ \alpha)$ за человеческими делами - приятнейшее из занятий, поскольку оно о том, что́ есть подлинного в нас самих» (О добродетелях, II.9).

Следующим благом после такой «феории» Плифон ставит естествознание, которое приносит «немалое прибавление в обретение счастья», поскольку занимающийся им человек «живет разумом» и пользуется им для рассмотрения всего, «наблюдая, что́ есть каждая вещь и благодаря чему она случается, что возможно по природе и что невозможно». Такой человек не довольствуется «ничтожными» человеческим радостями, но «обитает душой во всей этой вселенной, вкушая подлинное наслаждение», и живет жизнью, сходной с «лучшими родами», то есть с богами (O добродетелях, II.10). Франсуа Мазэ справедливо назвал эти рассуждения Плифона «гимном разуму и науке» [23, p. 257].

Из многочисленных научных интересов Плифона стоит привести в пример его занятия географией. Он изучал Страбона и, обратив на его сочинение внимание своих итальянских друзей, первым открыл его Западной Европе, где читали в то время одного Птолемея. Для своего времени Плифон был очень 
хорошим географом и, делая выписки из Страбона, старался сделать его доступным более широкой публике, причем самыми популярными из выписок Гемиста, судя по рукописям, стали те, где говорилось о форме и границах обитаемого мира. Эти вопросы живо интересовали и самого Плифона, который на основе более свежих свидетельств составил краткое Исправление к тексту Страбона, где, в частности, рассуждает о восточных границах обитаемой земли и выражает предположение, что существует некое восточное море и земли к востоку от Индии: «или за этими болотами, или даже за другой, следующей, землей по необходимости продолжается океан» [16, p. 445]. Реклама, данная Плифоном, привела к тому, что Гварино ди Верона перевел Страбона на латынь и он быстро стал на Западе влиятельнее Птолемея. Между тем именно Страбон был одним из главных авторитетов для Христофора Колумба, который ссылался на него, задумывая свою экспедицию в Индию западным путем ${ }^{5}$. Таким образом, Плифон, посодействовав развитию географических познаний на Западе, в какой-то мере стоял у истоков великих географических открытий Нового времени [15].

Подведем итоги взаимоотношений «Афин и Иерусалима» в византийском сознании. Можно сказать, что у первых христиан единственным городом был Иерусалим, что и понятно, с учетом их ожиданий близкого конца мира; у византийцев раннего периода Афины стали чем-то вроде сельского пригорода Иерусалима, откуда в город доставляется пища, но при этом само земледелие считается занятием низким; к XI в. Афины стали любимым местом отдыха интеллектуалов; византийские гуманисты палеологовской эпохи попытались сделать Афины второй столицей, уравняв с Иерусалимом, но этому процессу помешал паламитский спор; радикализм паламитов вызвал ответный радикализм Плифона, который сделал однозначный выбор в пользу Афин, совершенно отойдя от Иерусалима, в том числе и в религиозном плане.

Теперь можно только гадать, как сложилась бы судьба науки в Византии, если б Империя выжила. Конечно, если бы определенное влияние получили идеи Плифона, мы бы имели все шансы увидеть византийский Ре- нессанс. Но если бы идеологически победила партия Георгия Схолария, не только сжегшего Законы Плифона после смерти философа, но и призывавшего к физической расправе с инакомыслящими «эллинистами» $[9$, с. 44 54; 10, с. 264-279], в Византии, боюсь, могла бы появиться своя инквизиция.

Если верить Георгию Трапезундскому, на соборе во Флоренции по вопросу соединения церквей Плифон, бывший участником византийской делегации, утверждал, что скоро «всем миром как бы одной душой или одним разумом завладеет одна и та же религия», не христианская и не мусульманская, а эллинистическая; Гемист даже будто бы предрекал, что «через несколько лет после его смерти и мусульманство, и христианство падут и до крайних пределов земли воссияет подлинная истина» [9, с. 97]. Если считать, что Плифон действительно высказывал такое мнение, под «всем миром» разуметь мир цивилизованный, а под «падением» религий подразумевать сдачу их позиций перед лицом науки и секулярного мировоззрения, и учитывая гуманистическое содержание эллинизма самого Гемиста, можно сказать, что предсказание философа сбылось, - правда, он ошибся на несколько сотен лет.

\section{ПРИМЕЧАНИЯ}

1 Доклад на данную тему был прочитан мною на международной историко-философской конференции «Горизонты естествознания восточнохристианского Средневековья», Санкт-Петербург, 18-20.09.2015.

2 То есть религиозное - именно о нем идет речь у апостола.

3 Здесь и далее Законы Плифона цитируются в переводе И.П. Медведева по изданию [9, с. 221-290].

4 Здесь и далее этот трактат Плифона цитируется в переводе И.П. Медведева по изданию [9, c. 291-300], с моими изменениями по греческому тексту [17, p. 1-15].

${ }^{5}$ Страбон пишет о пути в Индию с запада следующее: «Посидоний предполагает, что переселение кимвров и родственных им племен из их родной страны произошло вследствие внезапного наступления моря. Наконец, Посидоний принимает, что длина обитаемого мира, составляющая около 70000 стадий, является половиной целой окружности, по которой она измерена, так что, говорит он, если плыть с запада прямым курсом, то можно 
достичь Индии, пройдя путь длиной в 70000 стадий» [14, с. 104-105, кн. II, гл. III.6].

\section{СПИСОК ЛИТЕРАТУРЫ}

1. Апостольские Постановления (через Климента, епископа и гражданина Римского) / пер. И. Новгородова. - СПб. : [б. и.], 2002. - 208 с.

2. Большаков, О. Г. Византия и Халифат в VIIХ вв. / О. Г. Большаков // Византия между Западом и Востоком. Опыт исторической характеристики / отв. ред. Г. Г. Литаврин. - СПб. : Алетейя, 2001. С. 354-379.

3. Василий Великий. Беседа 22. К юношам о том, как получать пользу из языческих сочинений // Святитель Василий Великий, архиепископ Кесарии Каппадокийской. Творения. В 2 т. Т. 1 / предисл. митр. Владимира ; вступ. ст. А. С. Сидорова. - М. : Сибирская Благозвонница, 2012. - С. 1054-1069.

4. Григорий Богослов. Слово 43, надгробное Василию, архиепископу Кесарии Каппадокийской // Святитель Григорий Богослов, архиепископ Константинопольский. Творения. В 2 т. Т. 1. - М. : Сибирская Благозвонница, 2010. - С. 510-552.

5. Григорий Палама. Триады в защиту священно-безмолвствующих / пер., послесл. и коммент. В. Вениаминова. - М. : Канон, 1995. - 384 с.

6. Лемерль, П. Первый византийский гуманизм. Замечания и заметки об образовании и культуре в Византии от начала до Х века / П. Лемерль ; вступ. ст. и пер. с фр. Т. А. Сениной (монахини Кассии). - СПб. : Свое издательство, 2012. - хіv, 490 с.

7. Любарский, Я. Н. Михаил Пселл: личность и творчество / Я. Н. Любарский // Две книги о Михаиле Пселле. - СПб. : Алетейя, 2001. - С. 183-529.

8. Макаров, Д. И. Антропология и космология св. Григория Паламы (на примере гомилий) / Д. И. Макаров. - СПб. : Изд-во Олега Абышко, 2003. $-544 \mathrm{c}$.

9. Медведев, И. П. Византийский гуманизм XIV-XV вв. / И. П. Медведев. - СПб. : Алетейя, 1997. $-342 \mathrm{c}$

10. Медведев, И. П. Геннадий Схоларий как идеолог «византийской инквизиции» / И. П. Медведев // Античная древность и средние века. - 2002.Вып. 33. - С. 264-279.

11. Прп. Максим Исповедник. Вопросы и недоумения / пер. с древнегреч. Д. А. Черноглазов ; науч. ред. Г. И. Беневич ; отв. ред. Д. А. Поспелов. М.; Св. гора Афон : Никея, 2010. - 488 с.

12. Платон. Собрание сочинений в 4 т. Т. 2 / пер. с древнегреч. ; общ. ред. А. Ф. Лосева [и др.]. - М. : Мысль, 1993.-528 с.

13. Сенина, Т. А. (монахиня Кассия). Иконопочитатели и иконоборцы IX столетия / T. А. Се- нина // Жития византийских святых эпохи иконоборчества / общ. ред. Т. А. Сениной (монахини Кассии). Т. І. - СПб. : Квадривиум, 2015. - С. 3-130.

14. Страбон. География : в 17 кн. / пер., ст. и коммент. Г. А. Стратановского. - М. : Наука, 1964. $944 \mathrm{c}$.

15. Anastos, M. V. Pletho, Strabo and Columbus / M. V. Anastos // Anastos M. V. Studies in Byzantine Intellectual History. - London : Variorum Reprints, 1979. - XVII.

16. Diller, A. A Geographical Treatise by Georgius Gemistus Pletho / A. Diller// Isis. - 1937. - Vol. 27. P. $441-451$.

17. Georges Gemiste Plethon. Traité des vertus / éd., introd., trad. et comm. par B. Tambrun-Krasker. Athens : Academy of Athens, 1987. $-128 \mathrm{p}$.

18. Gero, S. John the Grammarian, the Last Iconoclastic Patriarch of Constantinople. The Man and the Legend / S. Gero // Byzantina. - 1974-1975. Vol. 3-4. - P. 25-35.

19. Gouillard, J. Le Synodikon de l'Orthodoxie. Édition et commentaire / J. Gouillard // Travaux et mémoires. - 1967. - T. 2. - P. 1-316.

20. Kolias, G. Léon Choerosphactès, magistre, proconsul et patrice / G. Kolias. - Athens : Verlag der "Byzantinisch-Neugriechischen Jahrbücher", 1939. $140 \mathrm{p}$.

21. Krausmüller, D. Do we need to be stupid in order to be saved? Barlaam of Calabria and Gregory Palamas on Knowledge and Ignorance/ D. Krausmüller // Salvation according to the fathers of the church: the proceedings of the Sixth International Patristic Conference, Maynooth/Belfast, 2005 / ed. V. Twomey, D. Krausmüller. - Dublin : Four Courts Press, 2010. P. $143-152$.

22. Magdalino, P. Occult Science and Imperial Power in Byzantine History and Historiography $\left(9^{\text {th }}\right.$ $12^{\text {th }}$ Centuries) / P. Magdalino // The Occult Sciences in Byzantium / ed. P. Magdalino, M. Mavroudi. Geneva : La Pomme d'or, 2006. - P. 119-162.

23. Masai, F. Pléthon et le platonisme de Mistra / F. Masai. - Paris : Les Belles lettres, 1956. - 422 p.

24. Mavroudi, M. Occult Science and Society in Byzantium: Considerations for Future Research / M. Mavroudi // The Occult Sciences in Byzantium / ed. P. Magdalino, M. Mavroudi. - Geneva : La Pomme d'or, 2006. - P. 39-96.

25. Mertens, M. Graeco-Egyptian Alchemy in Byzantium / M. Mertens // The Occult Sciences in Byzantium/ ed. P. Magdalino, M. Mavroudi. - Geneva : La Pomme d'or, 2006. - P. 205-230.

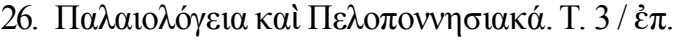

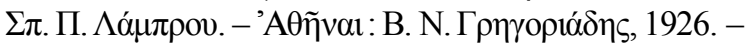
$372 \sigma$.

27. Siniossoglou, N. Radical Platonism in Byzantium: Illumination and Utopia in Gemistos 
Plethon / N. Siniossoglou. - Cambridge : Cambridge University Press, 2011. - $454 \mathrm{p}$.

28. Socrates' ecclesiastical history/ ed. W. Bright. Oxford: Clarendon Press, 1893. - xxiv, 343 p.

29. Tambrun, B. Pléthon. Le retour de Platon / B. Tambrun. - Paris : Vrin, 2006. -302 p.

30. Theodori Metochitae miscellanea philosophica et historica / ed. Ch. Muller et Th. Kiessling. - Lipsiae : Vogelii, 1821.-xvi, 838 p.

\section{REFERENCES}

1. Novgorodov I., ed. Apostolskie Postanovleniya (cherez Klimenta, episkopa i grazhdanina Rimskogo) [Apostolic Constitutions via Clement, Bishop and Citizen of Rome]. Saint Petersburg, 2002. 208 p.

2. Bolshakov O.G. Vizantiya i Khalifat v VII-X vv. [Byzantium and Caliphate in the $7^{\text {th }}-10^{\text {th }}$ Centuries]. Litavrin G.G., ed. Vizantiya mezhdu Zapadom $i$ Vostokom. Opyt istoricheskoy kharakteristiki [Byzantium between West and East. An Attempt of Historical Description]. Saint Petersburg, Aleteya Publ., 2001, pp. 354-379.

3. Vasiliy Velikiy. Beseda 22. K yunosham o tom, kak poluchat polzu iz yazycheskikh sochineniy [Basil of Caesarea. Oration 22. Address to Young Men on Usefullness of Pagan Works]. Vladimir, metropolitan, Sidorov A.S., eds. Svyatitel Vasiliy Velikiy, arkhiepiskop Kesarii Kappadokiyskoy. Tvoreniya. $V 2$ t. T. 1 [Saint Basil the Great. Works in 2 vols. Vol. 1]. Moscow, Sibirskaya Blagozvonnitsa Publ., 2012, pp. 1054-1069.

4. Grigoriy Bogoslov. Slovo 43, nadgrobnoe Vasiliyu, arkhiepiskopu Kesarii Kappadokiyskoy [Gregory the Theologian. Funeral Oration 43 tp the Great St. Basil]. Svyatitel Grigoriy Bogoslov, arkhiepiskop Konstantinopolskiy. Tvoreniya. V 2 t. T. 1 [Saint Basil the Great. Works in 2 vols. Vol. 1]. Moscow, Sibirskaya Blagozvonnitsa Publ., 2010, pp. 510-552.

5. Veniaminov V., ed. Grigoriy Palama. Triady v zashchitu svyashchenno-bezmolvstvuyushchikh [Gregory Palamas. Triads for the Defense of Those Who Practice Sacred Quietude]. Moscow, Kanon Publ., $1995.384 \mathrm{p}$.

6. Lemerle P. Pervyy vizantiyskiy gumanizm. Zamechaniya i zametki ob obrazovanii $i$ kulture $v$ Vizantii ot nachala do X veka [The First Byzantine Humanism. Notes and Remarks on Education and Culture in Byzantium from Its Origins to the $10^{\text {th }}$ Century]. Saint Petersburg, Svoe izd-vo, 2012. xiv, 490 p.

7. Lyubarskiy Ya.N. Mikhail Psell: lichnost i tvorchestvo [Michael Psellos: Person and Works]. Dve knigi o Mikhaile Pselle [Two Books about Michael Psellos]. Saint Petersburg, Aleteya Publ., 2001, pp. 183-529.
8. Makarov D.I. Antropologiya i kosmologiya sv. Grigoriya Palamy (na primere gomiliy) [Anthropology and Cosmology of St. Gregory Palamas as Reflected in his Homilies]. Saint Petersburg, Izd-vo Olega Abyshko, 2003. 544 p.

9. Medvedev I.P. Vizantiyskiy gumanizm XIV$X V v v$. [Byzantine Humanism of the $14^{\text {th }}-15^{\text {th }}$ Centuries]. Saint Petersburg, Aleteya Publ., 1997. 342 p.

10. Medvedev I.P. Gennadiy Skholariy kak ideolog «vizantiyskoy inkvizitsii» [Gennadius Scholarios as an Ideologist of Byzantine Inquisition]. Antichnaia drevnost $i$ srednie veka [Antiquity and the Middle Ages], 2002, vol. 33, pp. 264-279.

11. Chernoglazov D.A., Benevich G.I., Pospelov D.A., eds. Maximus the Confessor. Voprosy i nedoumeniya [Maximus the Confessor. Questions]. Moscow; St. Mount Athos, Nikeya Publ., 2010, 488 p.

12. Losev A.F., ed. Platon. Sobranie sochineniy v 4 t. T. 2 [Plato. Works in 4 vols. Vol. 2]. Moscow, Mysl Publ., 1993. 528 p.

13. Senina T.A. (nun Kassia). Ikonopochitateli i ikonobortsy IX stoletiya [The Iconophiles and the Iconoclasts of the Ninth Century]. Senina T.A. (nun Kassia), ed. Zhitiya vizantiyskikh svyatykh epokhi ikonoborchestva. T. I [The Lives of Byzantine Saints of the Iconoclastic Epoch. Vol. I]. Saint Petersburg, Kvadrivium Publ., 2015, pp. 3-130.

14. Stratanovskiy G.A., ed. Strabon. Geografiya: v $17 \mathrm{kn}$. [Strabo. Geography in 17 Books]. Moscow, Nauka Publ., 1964. 944 p.

15. Anastos M. V. Pletho, Strabo and Columbus. Anastos M.V. Studies in Byzantine Intellectual History. London, Variorum Reprints, 1979. XVII.

16. Diller A. A Geographical Treatise by Georgius Gemistus Pletho. Isis, 1937, vol. 27, pp. 441-451.

17. Tambrun-Krasker B., ed. Georges Gemiste Plethon. Traité des vertus. Athens, Academy of Athens, $1987.128 \mathrm{p}$.

18. Gero S. John the Grammarian, the Last Iconoclastic Patriarch of Constantinople. The Man and the Legend. Byzantina, 1974-1975, vol. 3-4, pp. 25-35.

19. Gouillard J. Le Synodikon de l'Orthodoxie. Édition et commentaire. Travaux et mémoires, 1967, vol. 2, pp. 1-316.

20. Kolias G. Léon Choerosphactès, magistre, proconsul et patrice. Athens, Verlag der "Byzantinisch-Neugriechischen Jahrbücher", 1939. $140 \mathrm{p}$.

21. Krausmüller D. Do we need to be stupid in order to be saved? Barlaam of Calabria and Gregory Palamas on Knowledge and Ignorance. Twomey V., Krausmüller D., ed. Salvation according to the fathers of the church: the proceedings of the Sixth International Patristic Conference, Maynooth/ 


\section{ВИЗАНТИЙСКИЙ МИР}

Belfast, 2005. Dublin, Four Courts Press, 2010, pp. 143-152.

22. Magdalino P. Occult Science and Imperial Power in Byzantine History and Historiography (9th12th Centuries). Magdalino P. and Mavroudi M., eds. The Occult Sciences in Byzantium. Geneva, La Pomme d'or, 2006, pp. 119-162.

23. Masai F. Pléthon et le platonisme de Mistra. Paris, Les Belles lettres, 1956. 422 p.

24. Mavroudi M. Occult Science and Society in Byzantium: Considerations for Future Research. Magdalino P. and Mavroudi M., eds. The Occult Sciences in Byzantium. Geneva, La Pomme d'or, 2006, pp. 39-96.

25. Mertens M. Graeco-Egyptian Alchemy in Byzantium. Magdalino P. and Mavroudi M., eds. The
Occult Sciences in Byzantium. Geneva, La Pomme d'or, 2006, pp. 205-230.

26. Lampros Sp. P., ed. Palaiologeia kai peloponnēsiaka. Vol. 3. Athens, Vas. N. Grēgoriadēs, $1926.372 \mathrm{p}$.

27. Siniossoglou N. Radical Platonism in Byzantium: Illumination and Utopia in Gemistos Plethon. Cambridge, Cambridge University Press, 2011. $454 \mathrm{p}$.

28. Bright W., ed. Socrates' ecclesiastical history. Oxford, Clarendon Press, 1893. xxiv, 343 p.

29. Tambrun B. Pléthon. Le retour de Platon. Paris, Vrin, 2006. 302 p.

30. Muller Ch., Kiessling Th., eds. Theodori Metochitae miscellanea philosophica et historica. Lipsiae, Vogelii, 1821. xvi, 838 p.

\section{Information about the Author}

Tatiana A. Senina (nun Kassia), PhD, Saint Petersburg State University of Aerospace Instrumentation, Bolshaya Morskaya St., 67, 190000 Saint Petersburg, Russian Federation; Sociological Institute, RAS, 7-ya Krasnoarmeyskaya St., 25/14, 190005 Saint Petersburg, Russian Federation, mon.kassia@gmail.com, http://orcid.org/0000-0001-8120-3499

\section{Информация об авторе}

Татьяна Анатольевна Сенина (монахиня Кассия), кандидат философских наук, Санкт-Петербургский государственный университет аэрокосмического приборостроения, ул. Б. Морская, 67, 190000 г. Санкт-Петербург, Российская Федерация; Социологический институт РАН, ул. 7-я Красноармейская, 25/14, 190005 г. Санкт-Петербург, Российская Федерация, mon.kassia@gmail.com, http://orcid.org/0000-0001-8120-3499 